\title{
Turbidite Fasies of Lower Penosogan Formation in Karanggayam Area, Kebumen, Indonesia
}

\author{
Yan Rizal ${ }^{1}$, Wahyu Dwijo Santoso ${ }^{1}$, Alfend Rudyawan ${ }^{1}$, Romy Ari Setiaji ${ }^{2} \&$ Eko Bayu Purwasatriya ${ }^{2}$ \\ ${ }^{1}$ Department of Geology, Institut Teknologi Bandung, Indonesia \\ ${ }^{2}$ Department of Geology, University of Jenderal Soedirman, Indonesia \\ Correspondence: Yan Rizal, Department of Geology, Institut Teknologi Bandung, Labtek IV, Jalan Ganesa 10, \\ Indonesia. E-mail: yan@gl.itb.ac.id \\ Received: March 25, 2018 \\ doi:10.5539/mas.v12n6p124 \\ Accepted: April 25, 2018 \\ Online Published: May 31, 2018
}

\begin{abstract}
A continuous clastic sedimentary rock outcrop in the Karanggayam Area, Kebumen represents the complete deep marine fan facies of the Middle Miocene Lower Penosogan Formation. Lithology association and vertical succession were observed from a 63 meters detailed measured section along the Karanggayam River. This study aims to identify and classify the turbidite succession as well as the depositional environment of the formation within the North Serayu Basin, Central Java.

From the bottom to top the Lower Penosogan Formation is divided into: A2, B2, C2, D2 and F2 facies which represents basin plain, overbank (levee and distal levee), crevasse splay, channel-fill and frontal splay facies respectively. Changes in the depositional environment are interpreted to be influenced by the dynamic changes in morphology and global climate change caused by underwater volcanic activity as a result of Middle Miocene tectonic activity.
\end{abstract}

Keywords: Penosogan Formation, facies, association facies, turbidite

\section{Introduction}

North Serayu Basin is an area that has a fairly large spread of deep-water sediments namely the Waturanda, Penosogan, and Halang Formations. These deep-water sediments captures the unique system which represent the various sedimentary structure caused by mixing flow mechanism.

Penosogan Formation is one of the deep-water marine formation overlooked by researcher. A little is known about its sedimentology. The continuous outcrop of Penosogan Formation in Karanggayam Area provides the detail observation of deep-water depositional environment system. Therefore, the study aims to identify facies change and determine the changes in the depositional environment.

\section{Methods}

The research took place along the Karanggayam River located at the Karanganom village in, Karanggayam district, Kebumen area, Central Java (Fig. 1). Sixty-three meters continuous outcrop of the lower part of the Penosogan Formation was the subject of this study. Detailed observation of the formation was carried out to obtain lithology association and vertical succession while chip samples were obtained for detailed petrography and facies analysis. 


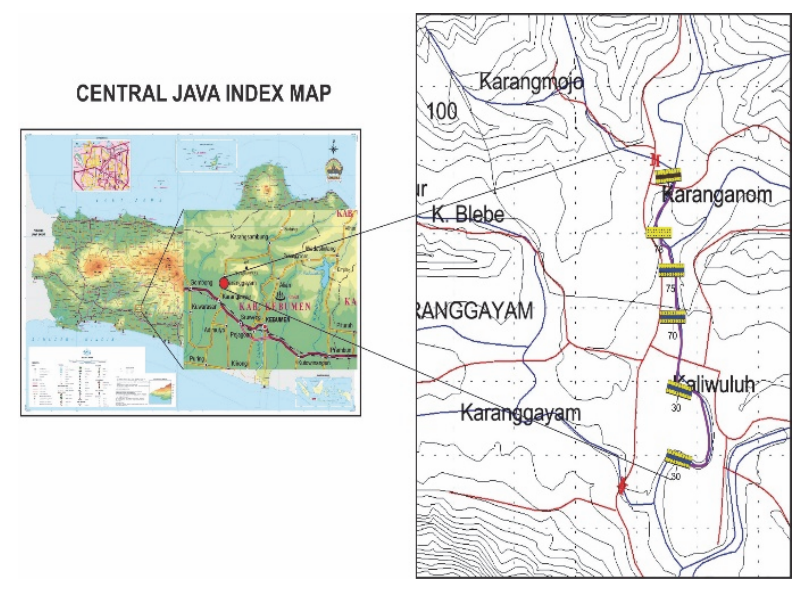

Figure 1. Location map of Research area

\section{Regional Setting}

Van Bemmelen (1949) divided the physiographic of Central Java into 7 morphology zones (north to south), namely: Alluvial plain of the North Java, Rembang - Madura Anticlinorium, Bogor - North Serayu - Kendeng Anticlinorium, Central Java Depression, Quaternary Volcano, South Serayu Mountains and South Java Mountains. The research area is located in Bogor - North Serayu - Kendeng anticlinorium (Fig.2). Figure 3 shows the local stratigraphy of the are put forward by Asikin et al. (1992)

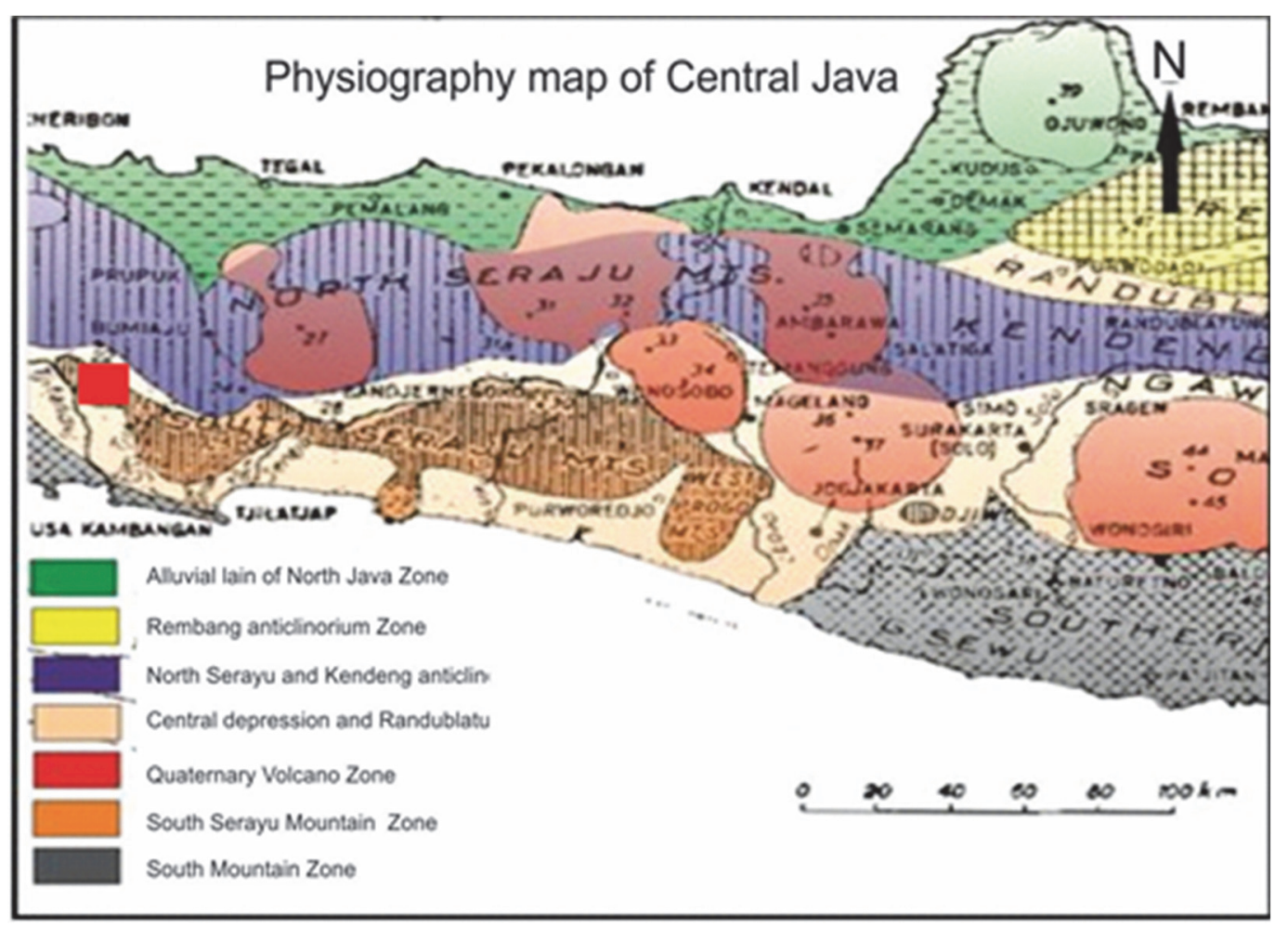

Figure 2. Physiography map of Central Java (Bemmelen, 1949) 


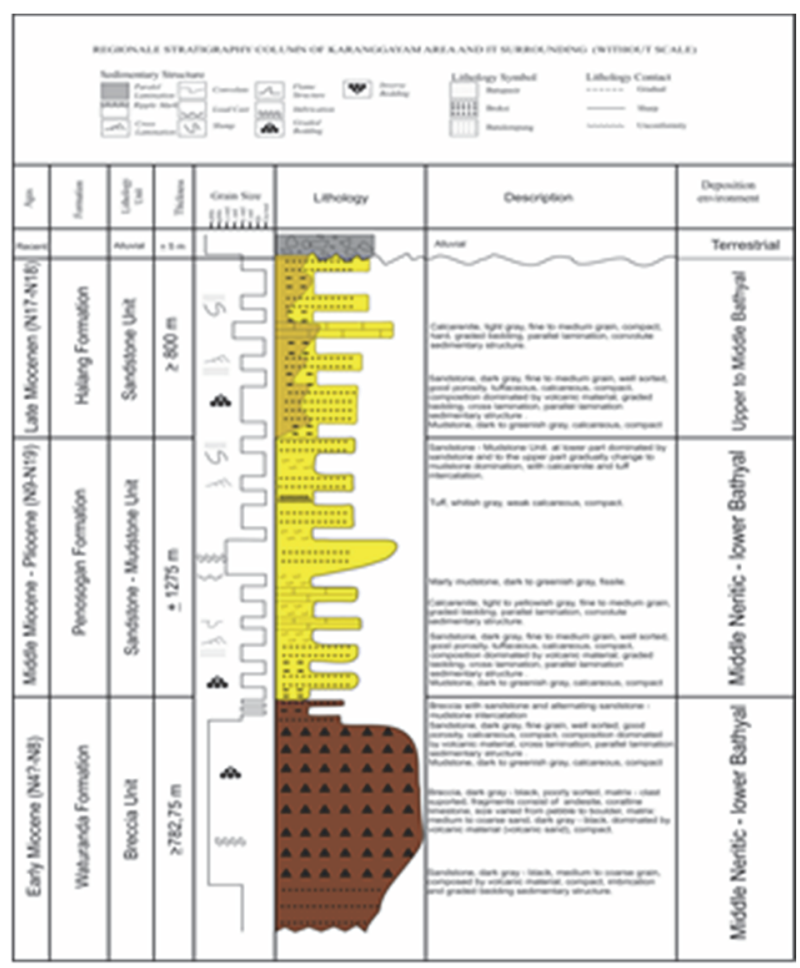

Figure 3. Stratigraphy of the research area (Asikin et al., 1992)

Lithofacies analyses were carried out following the Stow Classification (1985). Overall lithology association and vertical succession, sedimentary structures and the fossil content indicate that the Lower Penosogan Formation was deposited in via turbiditic mechanism in the deep marine environment. This study focuses in the facies analyses and their relationship adjusted to the turbidite facies models that already exist to ascertain the depositional environments in more detail and determine vertical succession that occurred in the study area (Figure 4). 

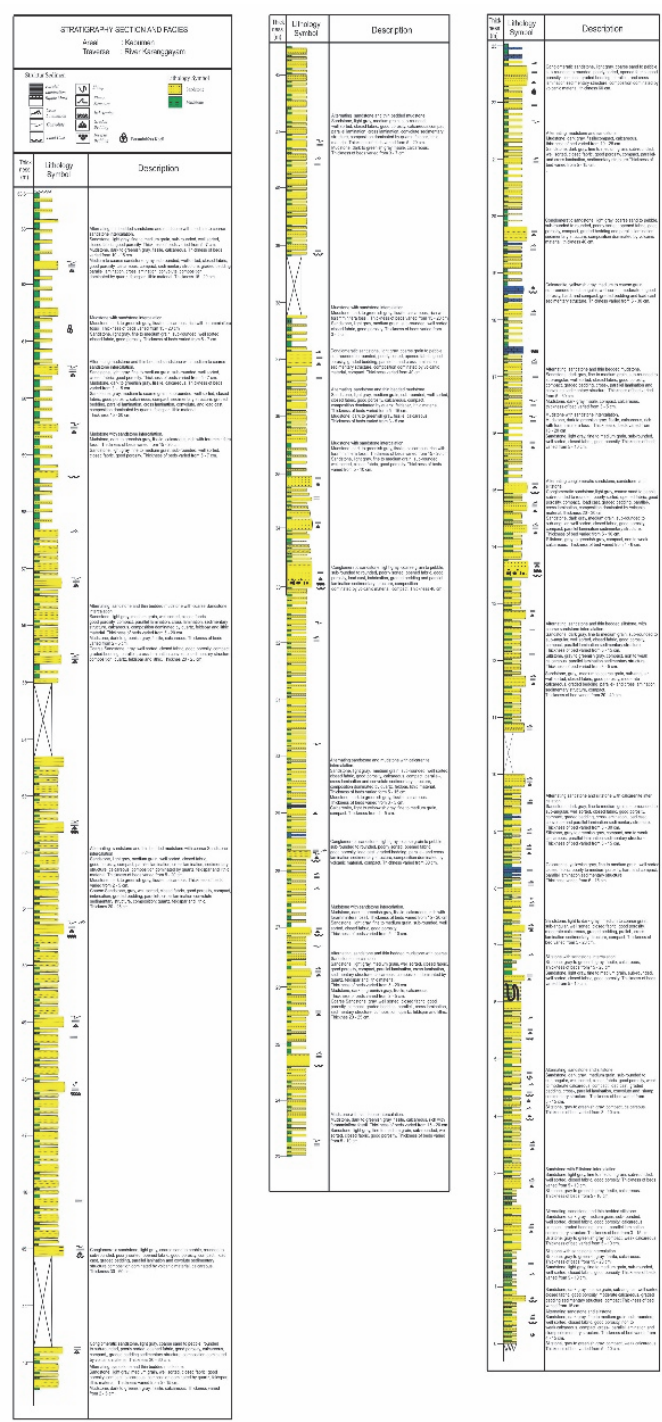

Figure 4. Detail Stratigraphy Column of the research area

\section{Deep Marine Turbidite Facies}

Gressly (1838) op.cit Reading (2001) stated that facies is part of the rock body that can be distinguished from the other rocks which formed in the specific conditions of sedimentation, thus indicates a specific depositional environment. Certain facies can be distinguished from the rocks above, below, even laterally in stratigraphically succession. Facies can be either grouped into facies associations or divided into sub-facies. Knowledge of deep marine turbidite still in a state of "crisis" because the data is a result of drilling and seismic sea fan in the modern is still very rare, so that the dimensions of deep marine fans and processes of sedimentation still questionable (Shanmugam, 2006). The interpretations of this deep marine turbidite in general refers to the ancient deep marine fan. Interpreting the ancient and modern analogues of deep marine fans needs to consider the following assumption:

- Each sub-depositional environment has the characteristics of an association of a specific deposition process,

- Sedimentation process that happens constantly all the time in the sub-deposition environment.

- All deep marine fans have identical facies development in each specific sub depositional environment (Shanmugam, 1988). Mutti and Ricci-Lucchi (1972) developed a model of the ancient deep marine fan facies which then later modified by Stow (1985; Figure 5). 

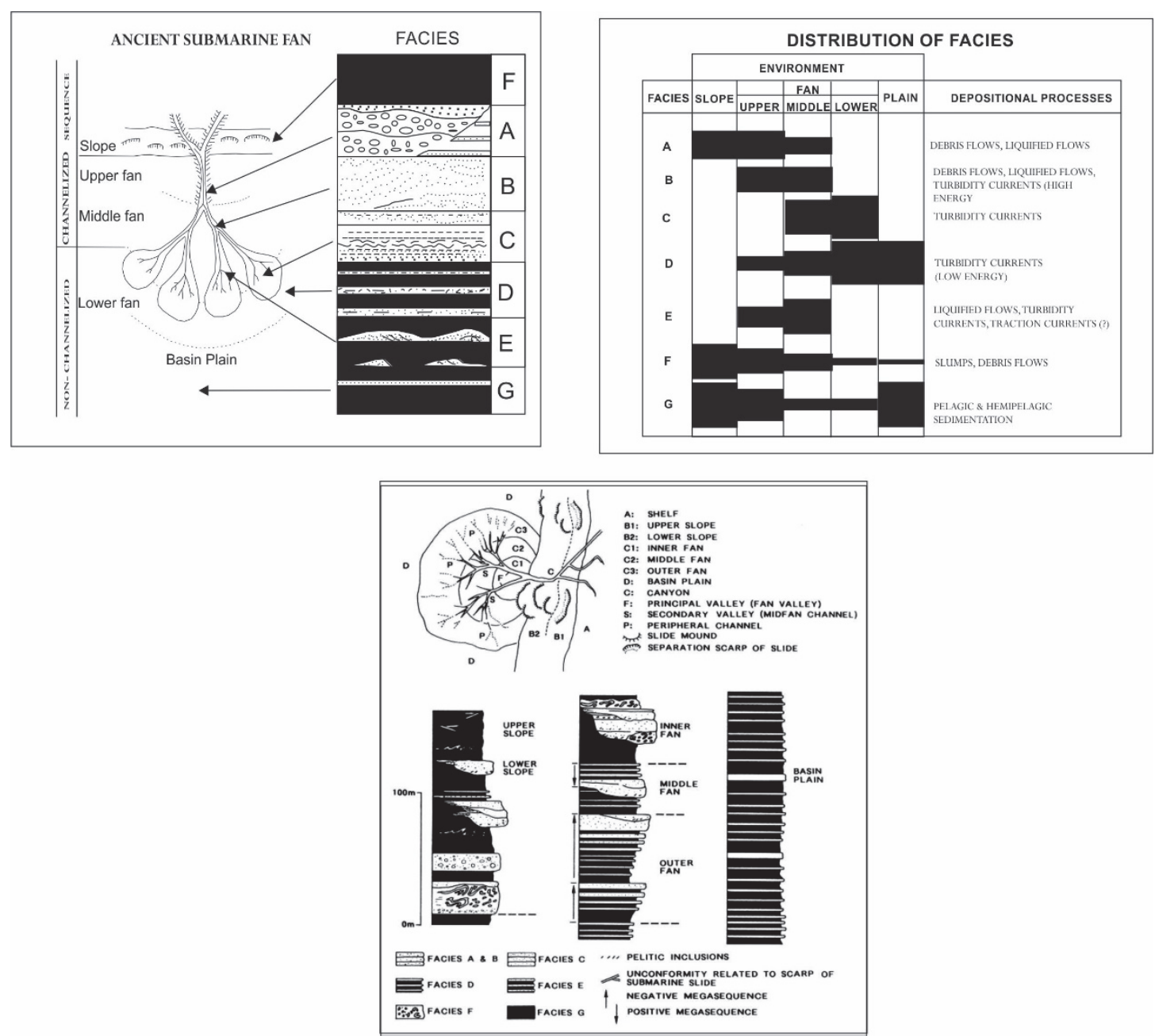

Figure 5. Modify facies models of Mutti and Luchi by D.A.V Stow, 1985

This facies models are then modified again by Stow (1985) and Pickering et al (1986). One of the modifications is used is classification modifications made by Stow (1985). This classification divides facies into 7 classes, 15 groups and 59 individual facies. 7 classes divided by grain size, internal arrangement, and composition (Figure 6). 


Class
A Gravels + Petwly Sand
A1

Figure 6. Stow Classification facies (1985)

A Class consists of conglomerates and conglomeratic sandstones with composition of gravel $>5 \%$. B Class is built up by sandstone with a composition $>80 \%$ sand and $<5 \%$ gravel. C Class consists of alternating sandstone and mudstone, muddy sandstone, with a composition of $20-80 \%$ sand and $<80 \%$ mud. D Class built up by siltstone, muddy siltstone, and alternating siltstone and mudstone with a composition $<80 \%$ mud, $\geq 40 \%$ silt, $0-20 \%$ sand. E Class consist of claystone with clay ratio $<95 \%,<40 \%$ silt, and $<5 \%$ sand and other coarse grains. F Class is chaotic deposits, such as slump. G Class built up by hemipelagic sediment with terrigenous composition $<5 \%$ (Stow, 1985).

15 groups differentiated by internal composition and texture. "Disorganized" facies refers to a group that does not have a clear stratification, such as conglomerate without sedimentary structures, massive sandstone, and bioturbated siltstone and mudstone. "Organized" facies is a group rocks which have a good stratification (bedding), graded bedding, parallel lamination, and cross-lamination. 59 other individual facies are distinguished based on their texture, internal structure, composition, and thickness of the layers. 


\section{Result and Discussion}

\section{Association Facies}

By using character of each facies unit and supported by their vertical succession pattern (facies association), the depositional environment can be determined. Based on their facies association from bottom to top the Sandstone - Mudstone unit contains the overbank (levee, distal levee, crevasse splay), channel-fill, frontal splay and basin plain facies, of a deep marine fan system. The detail facies succession is seen in figure 7 .
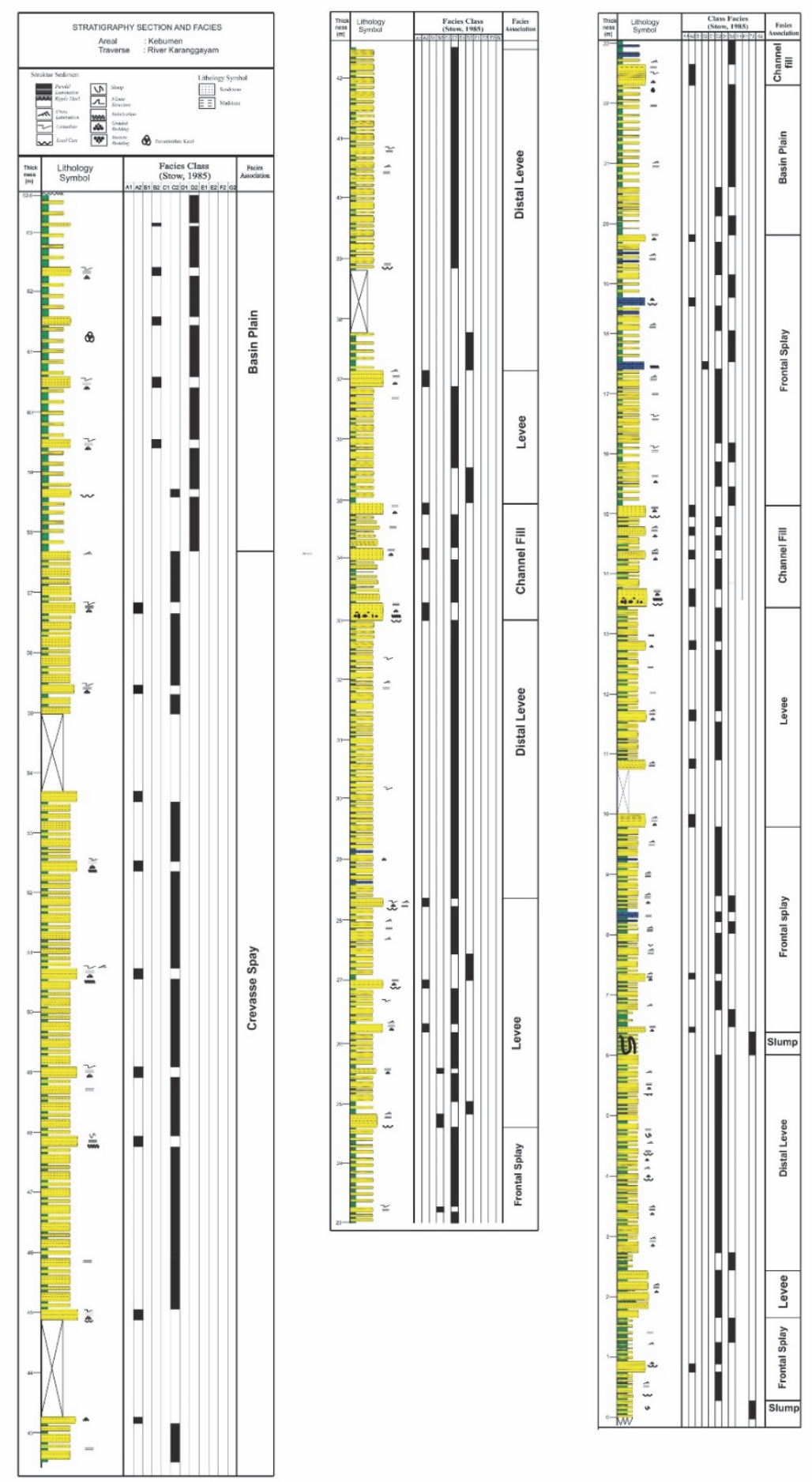

Figure 7. Association Facies of the section 


\section{Overbank}

The overbank deposits can be grouped into 3 facies association: levee, distal levee and crevasse splay.

\section{a. Levee}

This facies association consists of monotonous alternating sandstone and thin layer silty mudstone with intercalation coarse to conglomeratic sandstone (Fig. 8). The ratio of sandstone to silty mudstone is about $70 \%$. The maximum thickness of this facies association in one series can reach $2.2 \mathrm{~m}$ and the minimum thickness is 1 m.

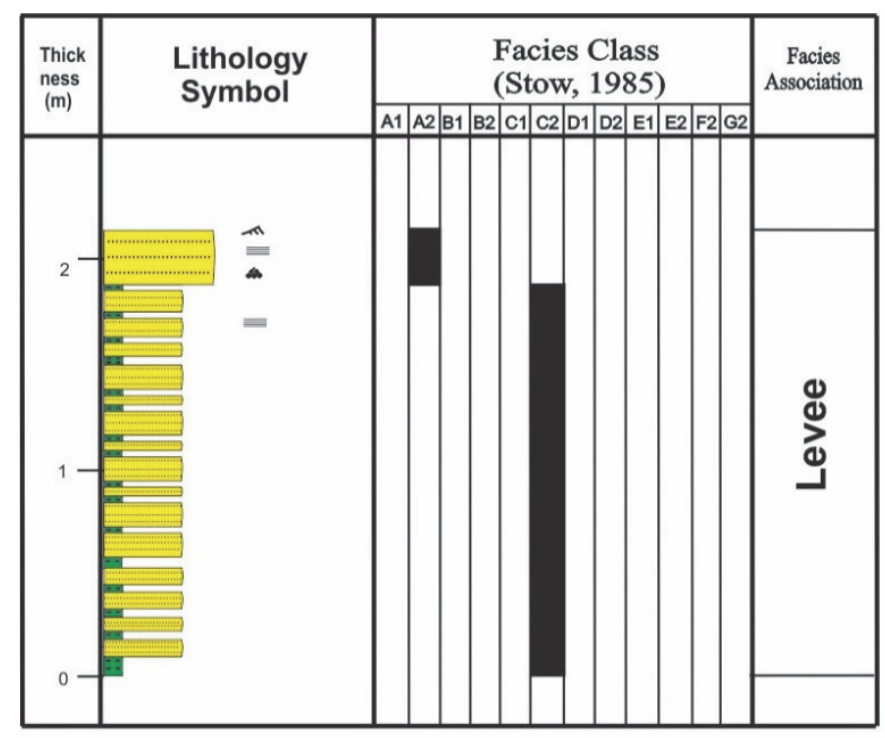

Figure 8. a selected succession of levee association facies

This levee association facies consisted of $\mathrm{C} 2$ and A2, which dominated by $\mathrm{C} 2$ facies.

C2 Facies consisted of alternating sandstones and thin layered silty mudstones with intercalation of A2 facies at upper part.

The silty-udstones unit is dark gray to greenish gray color, fissile and calcareous. Thickness of the silty mudstone varied from $5-15 \mathrm{~cm}$.

The andstones unit is gray, fine- to medium-grained, well sorted, closed fabric and indurated. The thickness of this sandstones is varied from $5-20 \mathrm{~cm}$.

A2 Facies characterized by medium- to coarse-grained sandstones, with erosional contact at the base and some bedding has parallel-, cross-lamination sedimentary structure (Fig 9) show as a part of a series T-bc of Bouma sequence.

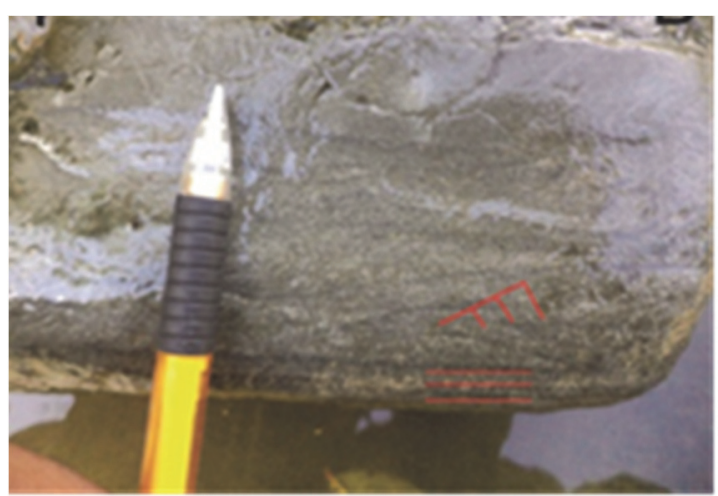

Figure 9. Cross-and parallel lamination in medium sandstone 
The sandstone unit (lithic wacke) is gray to dark gray color, medium- grained, well-sorted, medium porosity, composition dominated by quartz, feldspar, rock fragments and fossil fragments (Fig. 10). The thickness of this sandstone is about $40 \mathrm{~cm}$.

\section{Parallel Nicol}

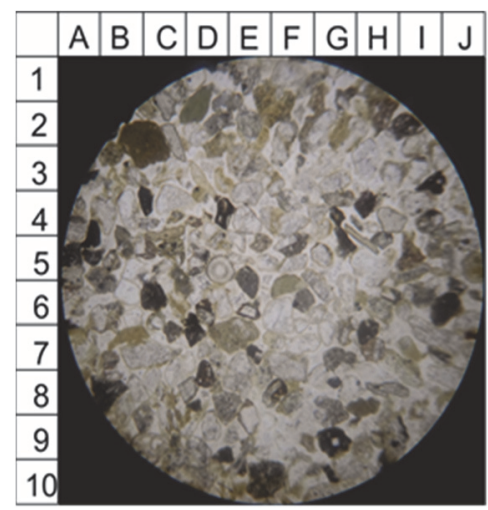

Cross Nicol

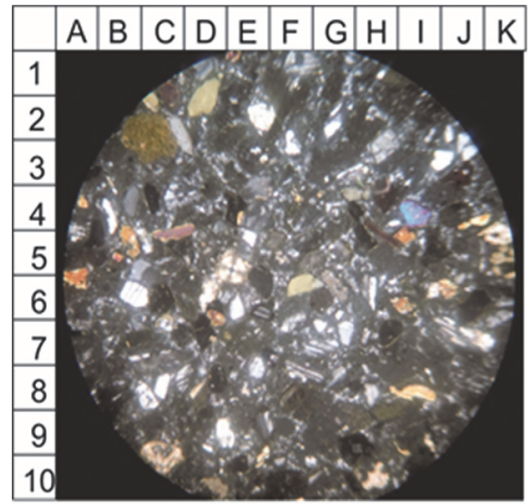

Figure 10. Petrography thin section of the sandstone (Lithic Wacke)

\section{b. Crevasse splay}

This association facies built up by $\mathrm{C} 2$ facies with $\mathrm{A} 2$ and $\mathrm{B} 2$ intercalation (Fig. 11).

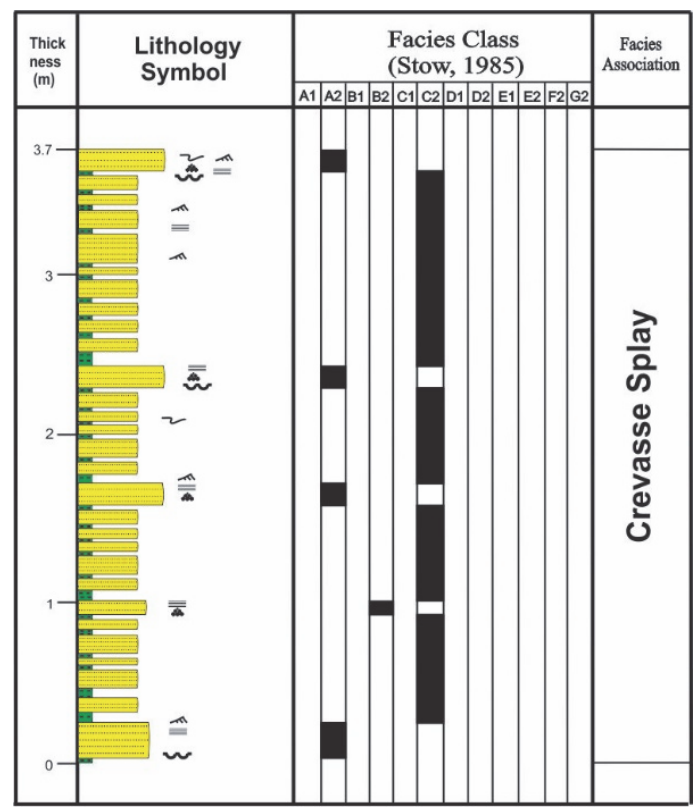

Figure 11. Selected Profile of crevasse association facies

C2 Facies consists of amalgamated sandstones with mudstone intercalation. The sandstones succession show fining upwards. The thickness of amalgamated sandstone varied from $5 \mathrm{~cm}$ to $15 \mathrm{~cm}$. The sandstones unit is gray, fine grained, well sorted showing parallel and cross lamination sedimentary structure and indurated.

The mudstones unit is gray to dark gray color, fissile and calcareous.

A2 Facies characterized by medium to coarse grained sandstones, with erosional contact at the base with parallel-, cross lamination sedimentary structure in some layers (Fig 11) suggesting a part of a series T-bc of Bouma sequence.

B2 Facies consist of medium-grained sandstones is gray with graded bedding and parallel lamination sedimentary 
structure.

\section{c. Distal levee}

The association facies consist of monotonous $\mathrm{C} 2$ facies of alternating fine grained sandstones and mudstones and calcarenite (Fig 12).

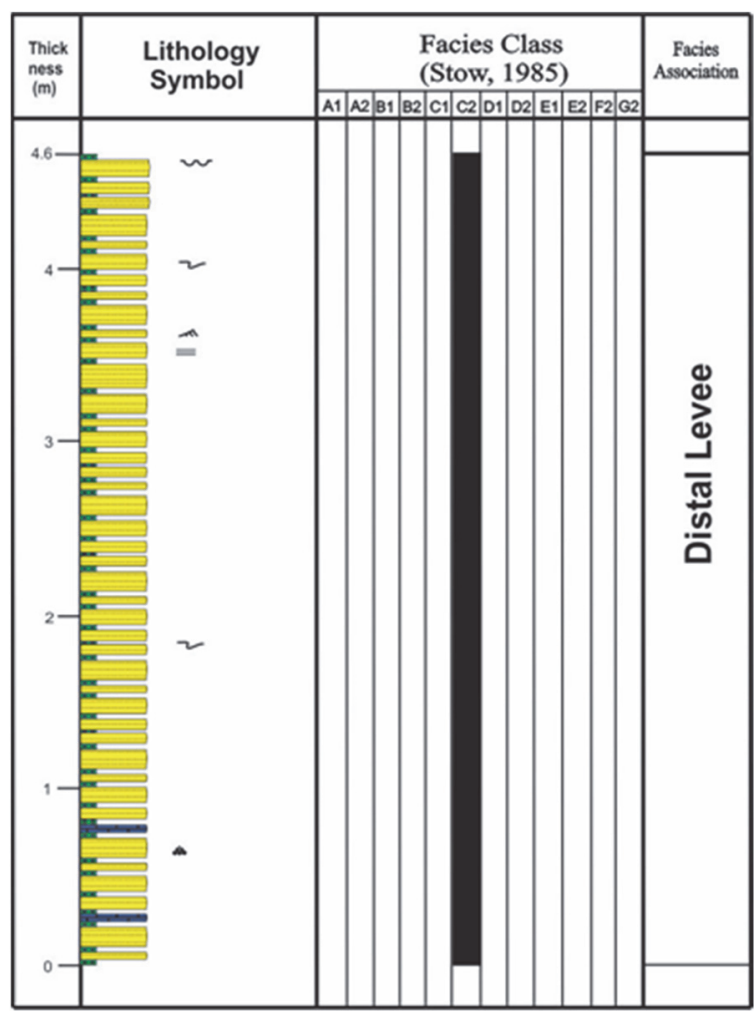

Figure 12. Selected Profile of distal levee association facies

\section{Channel Fill}

Channel fill association facies consists of facies A2 and C2. In a detail measured stratigraphic section (Fig. 13) the channel fill is built up by alternating conglomeratic sandstones, sandstones and siltstones. The thickness of facies associations varied from 1.7 - $2 \mathrm{~m}$ with sandstones ratio about $70-80 \%$.

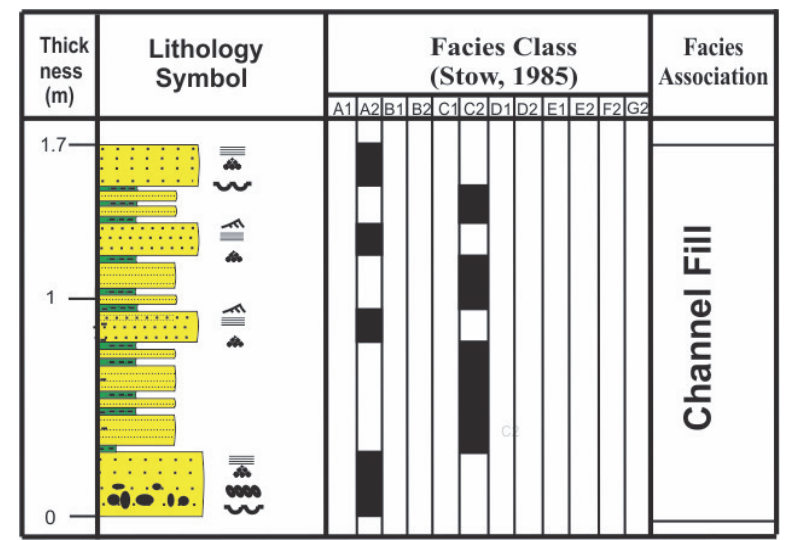

Figure 13. Selected profile of channel fill association facies 
A2 Facies characterized by light gray conglomeratic sandstones, clasts sizes ranges from coarse sand to pebble, sub-rounded to rounded, poorly-sorted, clasts floating in matrix, good porosity, indurated, showing load cast, graded bedding, parallel-, cross- lamination, scouring mark at base (Fig.14), clasts composition is dominated by volcanic material. The thickness of this unit ranges from $20-40 \mathrm{~cm}$.

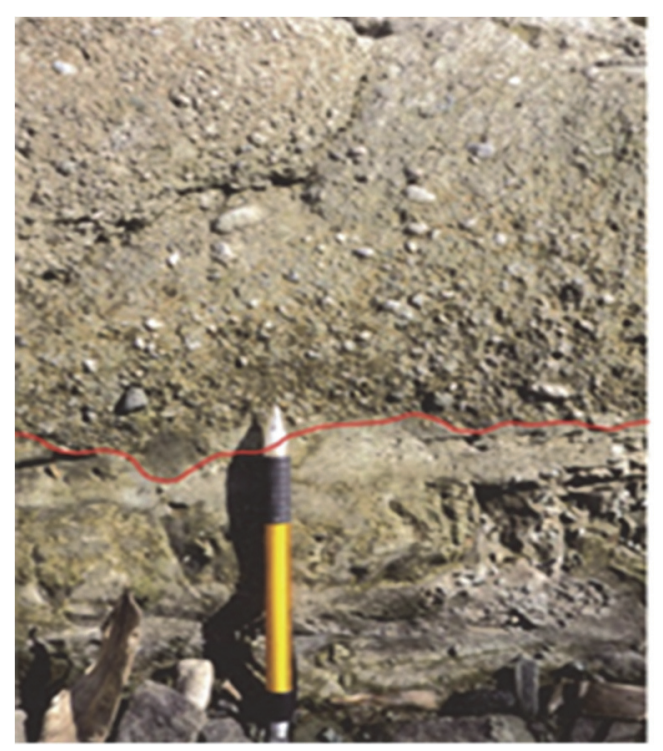

Figure 14. Scour mark at base of conglomeratic sandstone

The conglomeratic sandstone showed a series of Bouma sequence (Ta-e).

C2 Facies consists of amalgamated sandstone with mudstone intercalations. The sandstones succession show fining upwards. The thickness of amalgamated sandstone varied from $5 \mathrm{~cm}$ to $15 \mathrm{~cm}$. The sandstones unit is gray, medium-grained, angular to sub-angular, moderate - poorly sorted; clasts composition is dominated by lithic (volcanic rocks), a few quartz, cement silica, indurated. Some parts showing graded bedding, parallel lamination, wavy lamination and rip up clast (Fig.15).

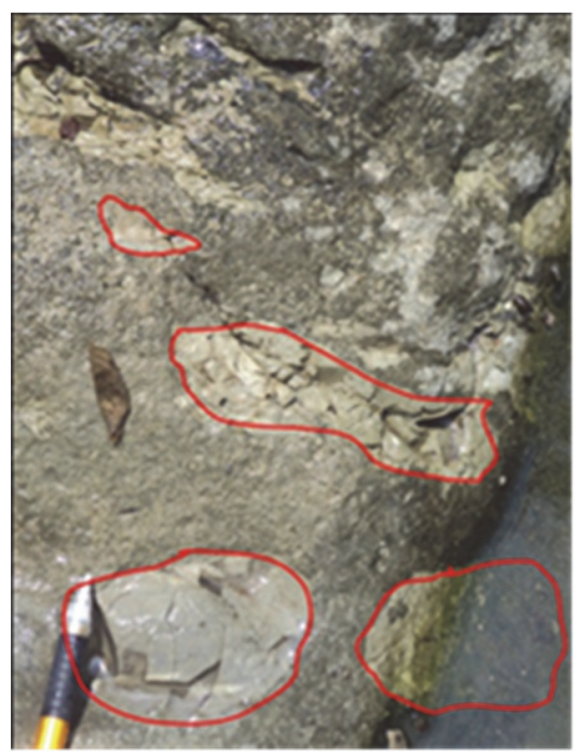

Figure 15. Rip-up mudstone clast at base of sandstone 


\section{Frontal Splay}

This association facies consists of alternating facies of C2, and D2 with A2, B2 intercalations (Fig. 16).

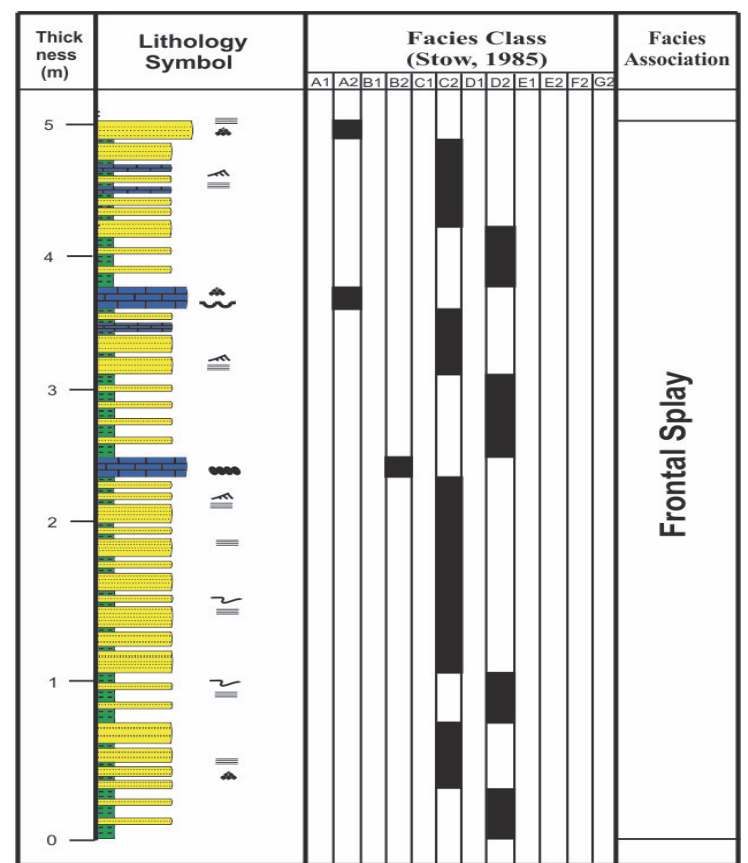

Figure 16. Selected Profile of frontal splay association facies

In the vertical succession the sandstone layer generally show coarsening and thickening upward. Scour marks are well developed at the base of the unit (Figure 17).
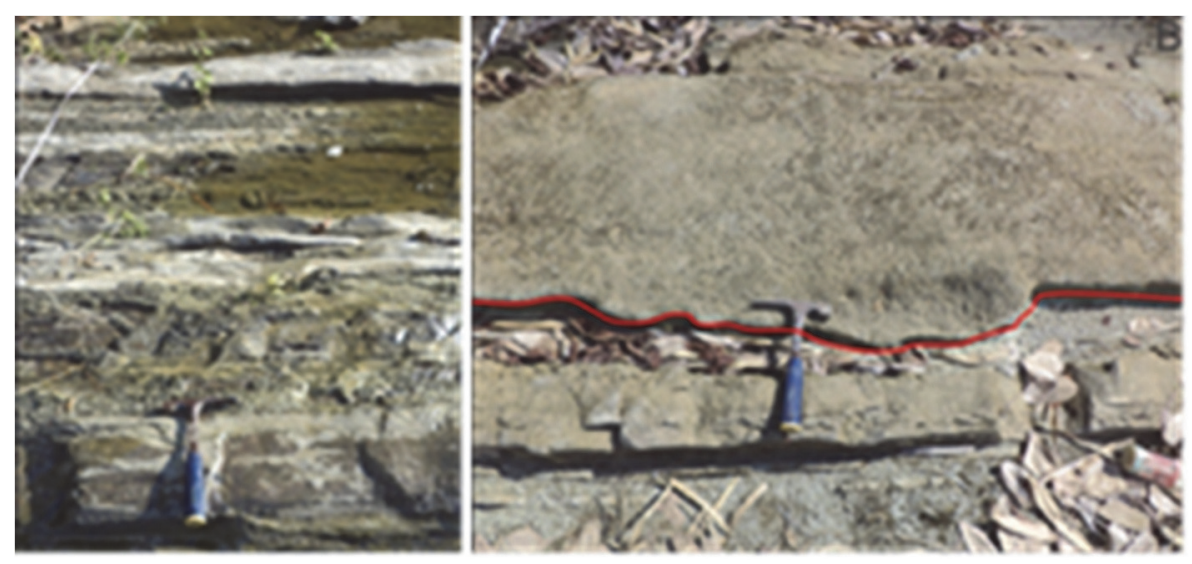

Figure 17. (left) Sandstone outcrop show a bed pattern as thickening upward, 18 (right) Scour mark at base of sandstone

The thickness of this association facies is about $5 \mathrm{~m}$, with sandstones ratio about $60 \%$.

C2 facies is characterized by alternating sandstones and thin bedded mudstones as well as limestones.

Sandstones (Feldspathic Wacke) unit is dark gray, fine- to medium- grained, sub-rounded to sub-angular, wellsorted, closed fabric, good porosity, indurated, graded bedding, cross-, parallel-lamination and convolute sedimentary structure (Fig. 18). Bed thickness varied from $5-30 \mathrm{~cm}$. 

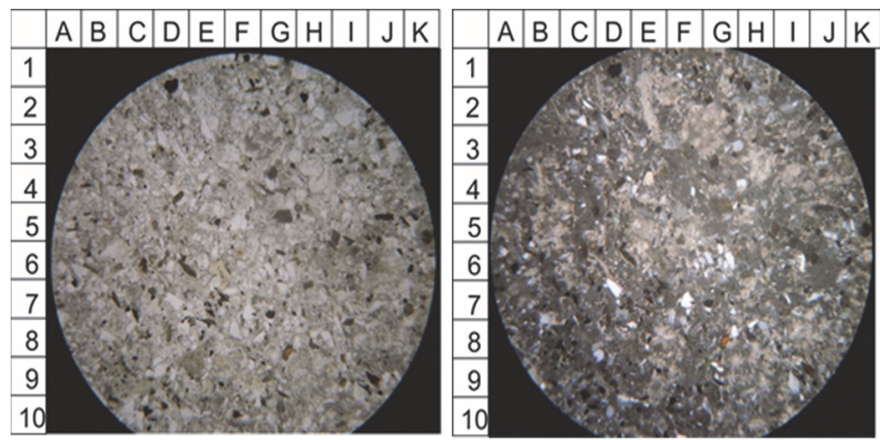

Figure 18. Petrography thin of Sandstone (Feldspathic wacke)

The mudstones unit is dark gray, fissile, indurated, calcareous, the thickness varied from $3-5 \mathrm{~cm}$. The limestones unit is light - whitish gray, fine-medium grained, rounded - subrounded, closed fabric, moderately-sorted (Fig. 19)

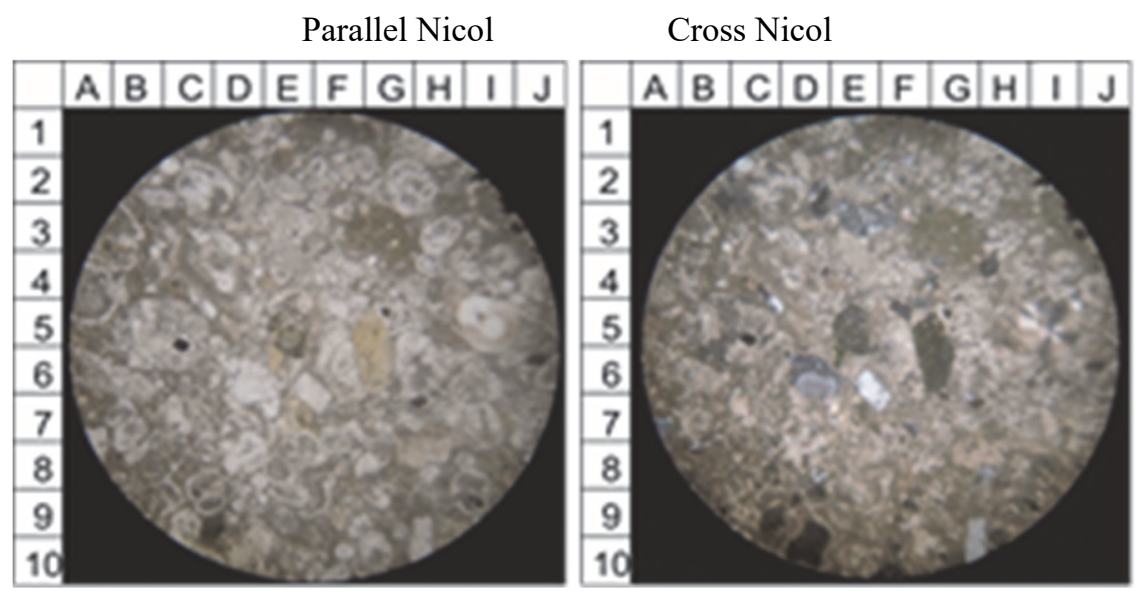

Figure 19. Petrography thin section of limestone (Packstone)

D2 facies consists of alternating of mudstones and silty-sandstones, with mudstones dominated. The mudstone unit has dark gray color, massive and contained foramminifera fossil. The thickness of the facies varied from 5-20 $\mathrm{cm}$.

The silty-sandstone has gray to dark gray color, fine to silt grain, well-sorted, medium porosity, contain microfossil fragments, lithic and a few quartz.

A2 Facies characterized by conglomeratic sandstones and limestones.

Conglomeratic sandstones unit is light gray, coarse sand to pebble, sub-rounded to rounded, poorly-sorted, good porosity, indurated. Load cast, graded bedding, parallel-, cross lamination are commonly observed along with, scouring mark at base. Clast floating in matrix and composed of predominantly volcanic material; the thickness of this facies varied from $20-40 \mathrm{~cm}$. The limestones (Packstone; Fig. 20) is light gray, fine- to coarse- grained, opened fabric, poorly-sorted, and indurated. Graded bedding is a common sedimentary structure. Sharp contact at the base of the unit. 
Parallel Nicol

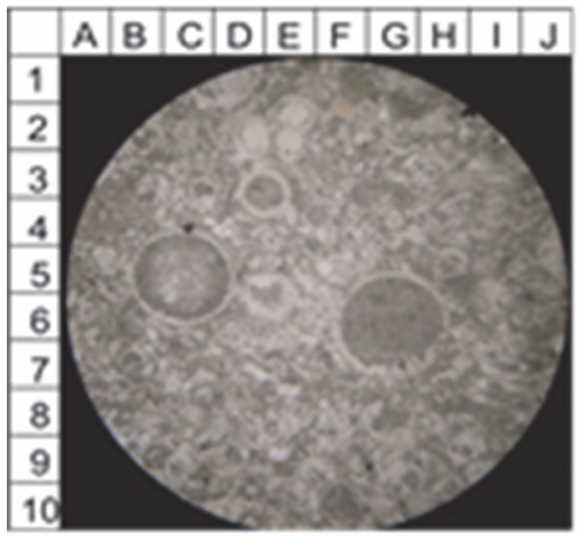

Figure 20. Petrography thin section of limestone (Packstone)

\section{Basin Plain}

The basin plain association facies consists of alternating D2 facies and B2 facies with C2 facies intercalations (Fig. 21) with thickness ranges between $2.5-5.6 \mathrm{~m}$.

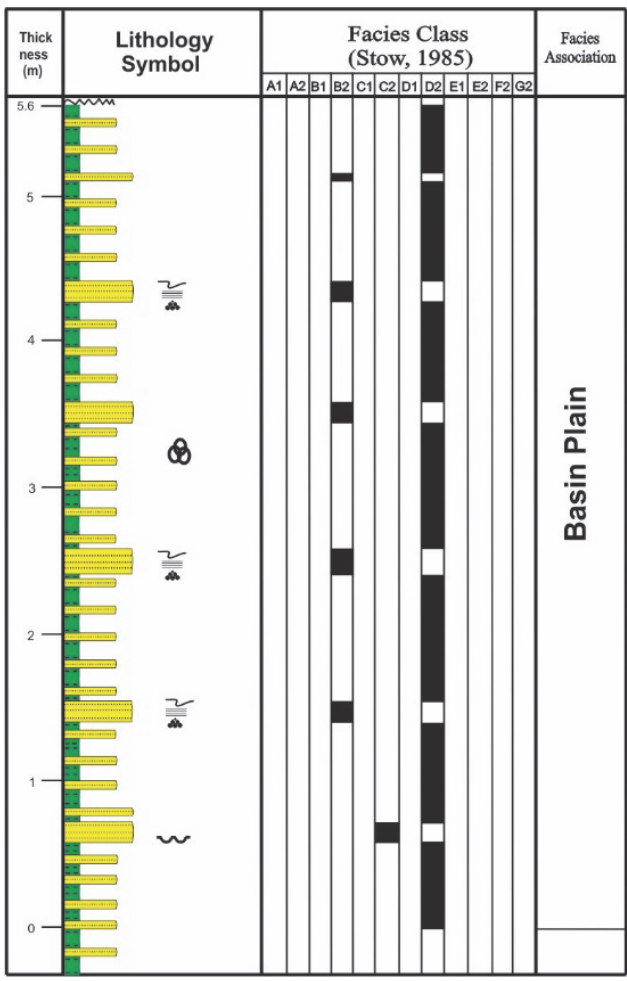

Figure 21. Selected Profile of Basin plain association facies

D2 facies consist of alternating mudstones and sandstones (Fig. 22)

The mudstones unit is dark gray, massive, brittle, calcareous, contained rich foraminifera fossil, and locally rich with bioturbation such as Thallasionoides, Zoophycos, and Skolithos. The sandstones unit (Feldspathic wacke) has gray to dark gray color, fine to silt grain, sub-rounded, well-sorted, medium porosity. Clasts composed of microfossil fragments, feldspar, plagioclase, and quartz crystals. The thickness of the sandstones unit ranges from $5-7 \mathrm{~cm}$. 

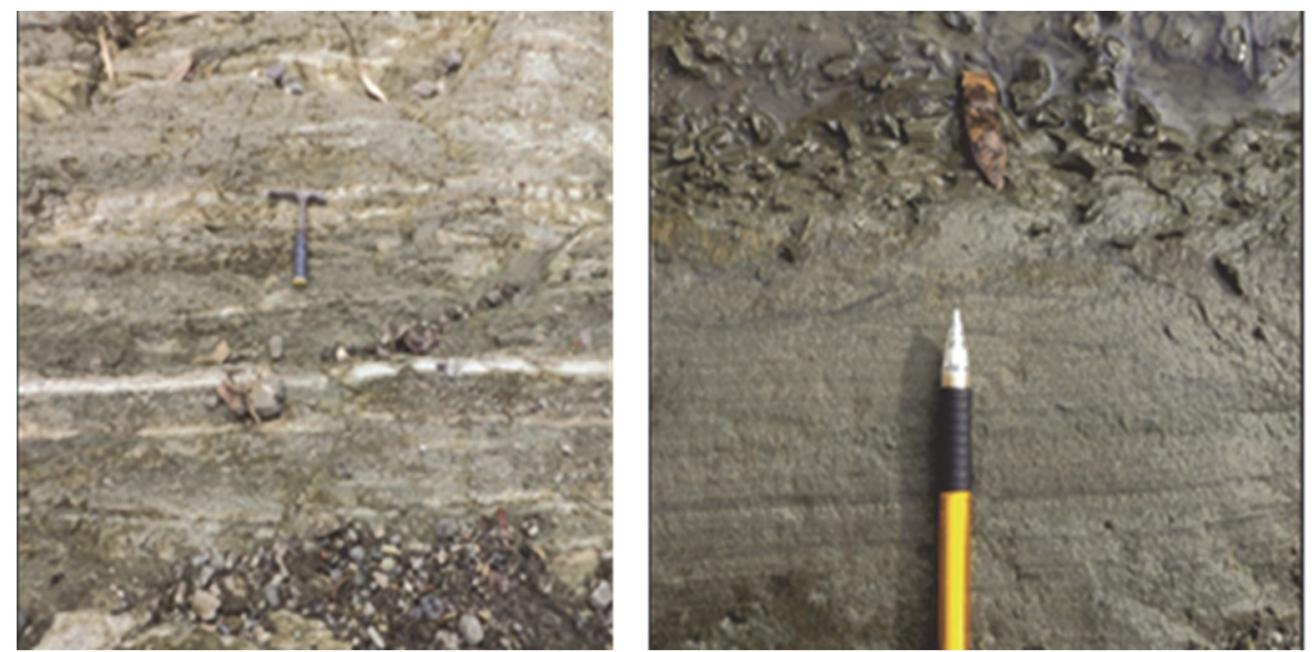

Figure 22. (left) Outcrop of alternating mudstone and sandstone. (Right) parallel- and cross lamination sedimentary structure in sandstone.

B2 facies built up by medium - coarse grained sandstones, erosional contact to lower layer and some layers showing graded bedding, parallel-, cross lamination and convolute sedimentary structure representing T-abc series of Bouma sequence. The thickness variation of this facies is $15-20 \mathrm{~cm}$.

\section{Interpretation}

Depositional environment of Lower Penosogan Formation

a. Submarine overbank

Monotonous alternating sandstone and silty mudstone (Facies C2) and intercalation of medium to coarse grained sandstone with an erosional contact, graded bedding, parallel-, cross lamination and convolute sedimentary structure, can be interpreted as the facies succession representing overbank (levee) of submarine fan. According to Mutti and Nomark (1987), this succession is belongs to overbank deposit of channel on deep sea fan. "Overbank" itself refers to the depositional environment that is periphery of the channel, so Lowe (1982) called a deposits as a results of a non-channelized turbidite, that commonly contain Bouma sequences.

\section{b. Channel fill}

The vertical succession of this facies association mostly consists of conglomeratic sandstone to sandstone which shown a bed pattern fining and thinning upward and silty mudstone contain rip up clast of mudstone. This combination is interpreted as a product of turbidity flow in mid fan channel of deep marine fan; thus categorized as non-classical turbidite deposition (Mutti and Luchi; 1972, 1975).

\section{c. Frontal splay}

This facies association can be categorized as lobe deposits of the deep sea fan (Mutti and Lucchi, 1972, 1975; Figure 23). The lobe, in the submarine fane, is positioned at the transition point of the channel, where levee a bypassed by the flow of turbidite from the channel. The overflow of channel will generate a new deposit, so-called lobe (Posamentier and Kola, 2003; Figure 24). Consequently, this lobe deposit will be associated with deposit of the channel of deep marine fan. The lobe deposits often observed directly above the channel deposits of deep marine fan. 


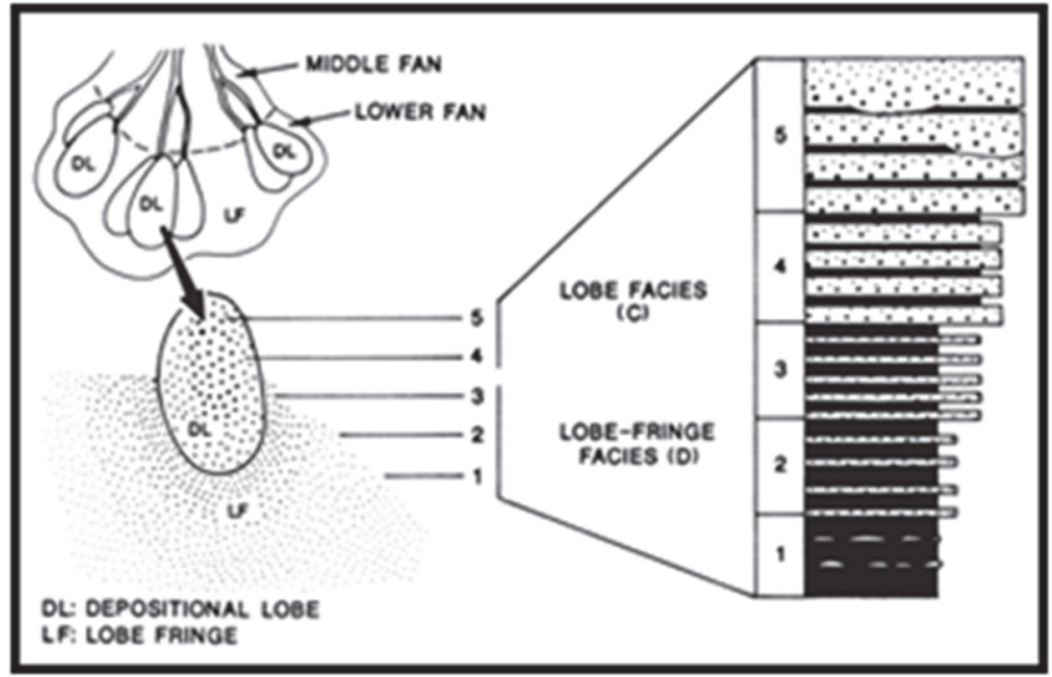

Figure 23. Lobe facies Model (frontal splay) of deep marine fan (Modified from Mutti, 1972 in Shanmugam, 2006)

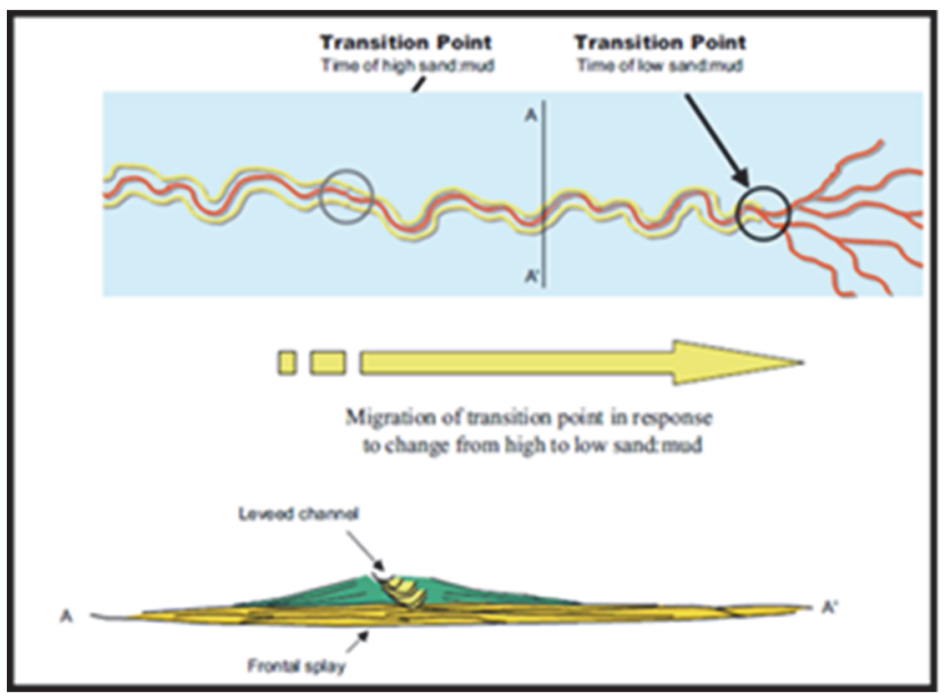

Figure 24. Sketch map and cross section of leveed channel and frontal splay (Posamentier and Kola, 2006)

\section{d. Basin plain}

The vertical succession of the basin plain facies association is dominated by alternating mudstones and thin layered sandstones. The mudstones deposited as pelagic sediment where the sedimentation is controlled by suspension process. Therefore life thrive under this condition as represented by the abundance presence of bioturbation (Thallasionoides, Zoophycos, and Skolithos) and foraminifera fossils. Thin layered sandstone is deposited under control of low velocity traction current while the presence of alternating medium - coarse grained sandstone with graded bedding, parallel lamination and convolute sedimentary structure indicating product of medium to high energy turbidity current.

The association facies of the lower Penosogan Formation in the study area built up by of overbank deposits (levee, distal levee and crevasse splay), channel-fill, frontal splay, and basin plain (Figure 25).

In summary, the depositional environment of the Lower Penosogan Formation is interpreted to be basin plain nonchannelized submarine fan (Shanmugam and Moiola, 1988) with periodic supply of coarse material.

The dominant volcanic material shows the existence of volcanic activity which is thought to be a submarine volcano that becomes a primary source of sedimentation. Increasing volcanic activity is recorded towards younger 
sequences as represented by the dominant composition of volcaniclastic material within the coarse clastics sedimentary units.

Figure 26 presented the summary of the vertical succession of the lower Penosogan Formation.

Changes in the depositional environment at the bottom were more frequent relative to the upper sequence as indicated by the thickness of each facies association.

These changes represent the influence of underwater volcanism activity or local tectonic activity that has an impact on submarine morphological changes.

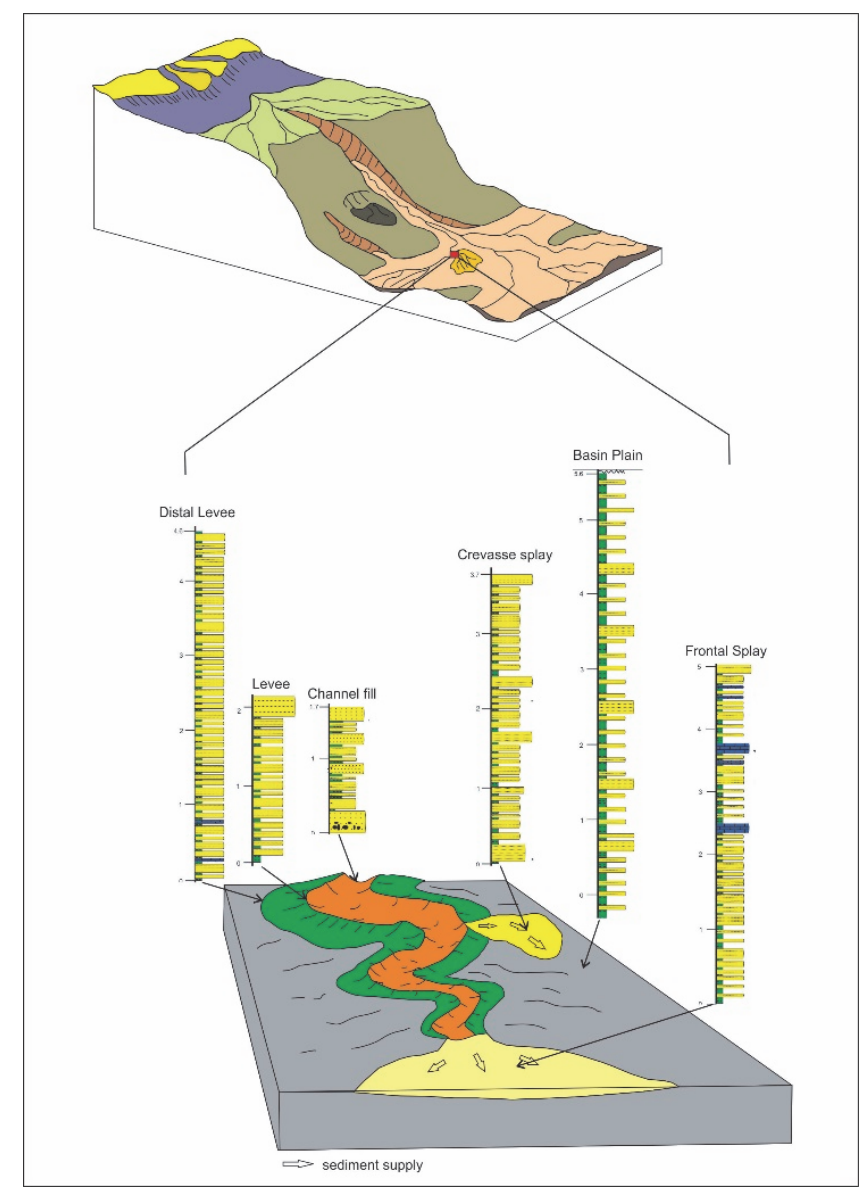

Figure 25. Deposition model of Lower Penosogan Formation 


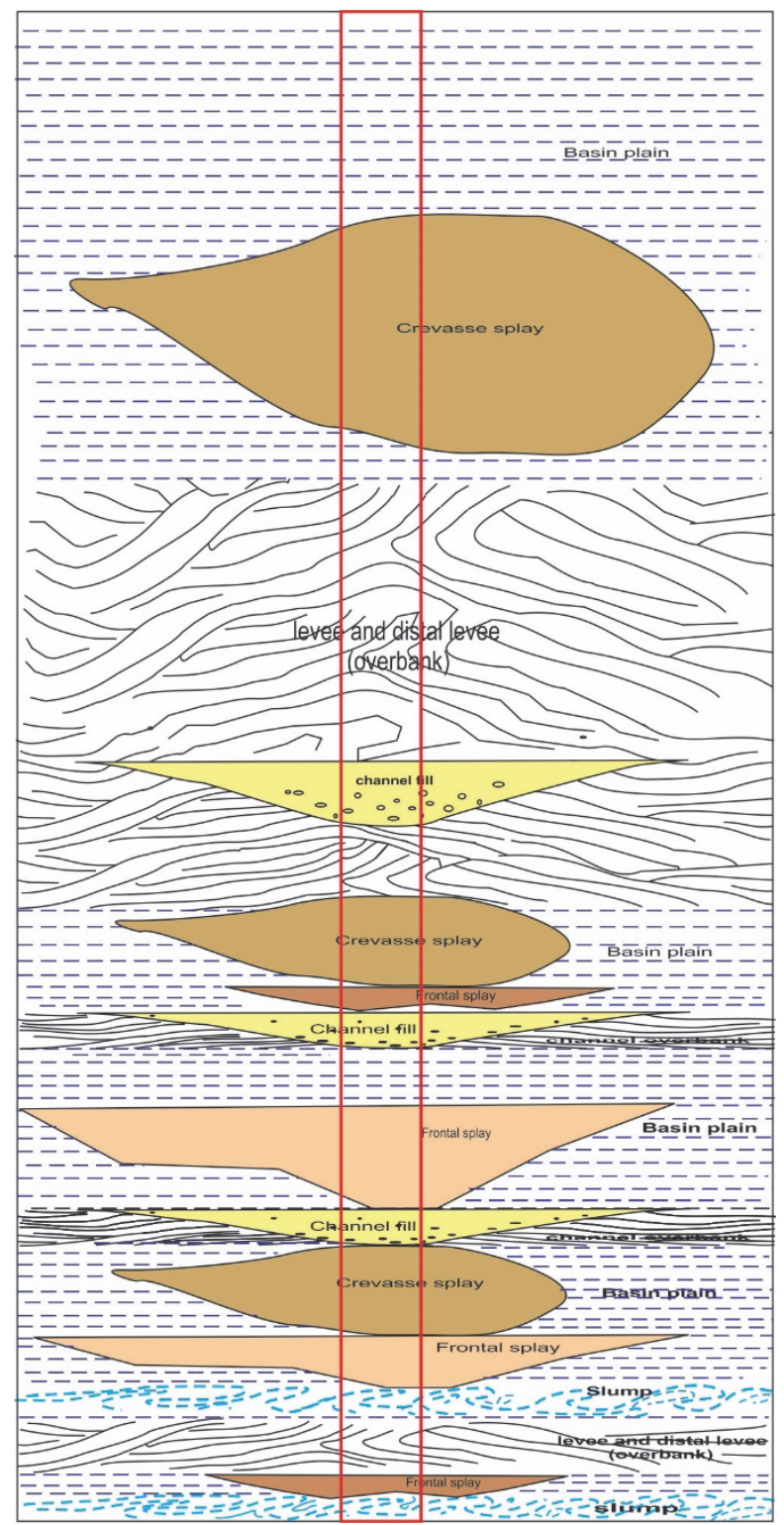

Figure 26. Sketches Changes in vertical Deposition environment

\section{Conclusion}

The lower part of Sandstone - Mudstone Unit of Penosogan Formation consists of A2, B2, C2, D2 and F2 facies with an association facies deposited in the deposition environment of Basin Plain, Overbank (levee and distal levee), Crevasse splay, Channel-fill and Frontal Splay of deep marine fan.

Facies analyses and facies association of this deep marine fan indicating Middle Fan (Overbank, Crevasse Splay, Channel-fill facies association), Outer Fan (Frontal Splay), and Basin Plain deposits.

Dynamic changes in the depositional environment are thought to be changes in morphology influenced by underwater volcanism, tectonic activity and global climate change during the Middle Miocene.

\section{References}

Asikin, S., Handoyo, A., Busono, H., \& Gafoer, S. (1992). Peta Geologi Lembar Kebumen, Jawa Tengah Skala 1: 100.000. Pusat Penelitian dan Pengembangan Geologi: Bandung

Guidebook A-11. Int. Sediment. Congr., IX, Nice, pp. 21-36.

Lowe, D. R. (1982). Sediment Gravity Flows: II. Depositional Model with Special Reference to the Deposits of High Turbidity Currents. Journal of Sedimentary Petrology, 52. 
Mutti, E., \& Ricci Lucchi, F. (1972). Turbidites of the Northern Apennines: Introduction to facies analysis (English translation by T.H. Nilsen, 1978). Int. Geol Rev., 20, 125-166.

Mutti, E., \& Ricci Lucchi, F. (1975). Turbidite facies and facies associations. In: Examples of Turbidite facies and Facies Associations from Selected Formations of the Northern Apennines. Field Trip.

Mutti, E., \& Nomark, W. R. (1987). Comparing Example of Modern and Ancient Turbidite Systems: Problems and Concept.

Posamentier, H. W., \& Kolla, V. (2003). Seismic Geomorphology and Stratigraphy of Depositional Setting in Deep Water System. Journal of Sedimentary Research Vol 73. Society for Sedimentary Geology.

Reading, H. G. (2001). Clastic Facies Models, A Personal Perspective, Bulletin of the Geological Society of Denmark vol. 48.

Shanmugam, G. (2006). Deep-Water and Facies Model: Implication for Sandstone Petroleum Reservoir. Elsevier Publishing Company. Amsterdam.

Shanmugam, G., \& Moiola, R. J. (1988). Submarine Fans: Characteristics, Models, Classification, and Reservoir Potential. Earth-Science Reviews, 24(1988), 383-428. Elsevier Science Publishers B.V., Amsterdam--Printed in the Netherlands

Van Bemmelen, R. W. (1949). The Geology of Indonesia. Nederland: Martinus Nyhoff, the Haque.

\section{Copyrights}

Copyright for this article is retained by the author(s), with first publication rights granted to the journal.

This is an open-access article distributed under the terms and conditions of the Creative Commons Attribution license (http://creativecommons.org/licenses/by/4.0/). 